\title{
Research on the Innovation of Residential Property Management Under Internet Thinking
}

\author{
Yan Yang \\ Chengdu Polytechnic \\ Chengdu, China
}

\begin{abstract}
After years of development, residential property management has shown some drawbacks. Under the background of "Internet plus", there are some innovative models in property management. How to make better use of Internet thinking and improve the professionalization and modernization level of residential property management is the topic that still should be explore at this time.
\end{abstract}

Keywords-residential property management; internet thinking; innovation

\section{INTRODUCTION}

After years of development, China's property management industry has achieved tremendous development. According to the main data bulletin of the Third National Economic Census, up to the end of 2013, property management reached 105,000 , and the number of property employees was 4.116 million. In recent years, it is constantly developing. Residential property management, one of the directions of property management, mainly refers that the department of property management, entrusted by the owners and the users, carries out maintenance, repair and remediation on the housing construction of property and the management project such as its supporting facilities, equipment, greening, sanitation, public security and environmental appearance according to the property management contract and collect management fees from owners and users in accordance with the property management contract and relevant regulations. The development of residential property management has improved the quality of people's living and promoted employment and national economic development. But overall, the industry is still operating at a low to medium level.

\section{OPERATION STATUS OF RESIDENTIAL PROPERTY MANAGEMENT}

\section{A. Uneven Development Level of Residential Property Management}

At present, most of China's residence communities are equipped with property management services, but the property management and operation conditions are very different, which can mainly be divided into three types. The first is an old residential area dominated by the family house for companies. There is almost no property management. It is simply equipped with a doorman, simple cleaning service in the public area. The monthly cleaning fee is provided by the household. The salary of the community guard is paid by the company. There is no consciousness of property service, so the owners cannot enjoy more services such as maintenance and greening, etc. There are more tenants in the community, and outsiders bring a series of unsafe hidden dangers. The second is the community built in the past ten years. The property management mainly includes the "four guarantees" service: cleaning, security, green protection, and guarantee repair. Due to years of use, there are problems such as aging facilities, damaged elevator, falling off outer wall, and the insufficient parking space, so the owners and property management companies have more conflicts; property fees are charged according to the housing area, maintaining the original level for many years. However, with the increase in labor expenditures and maintenance expenditures, the property management companies have suffered more losses, and some enterprises even lower the service level to ensure their own profit. Third, large-scale well-known residential community such as Vanke, Fantasia, and Longhu, etc., began the "Internet + Property" management model, which integrates information technology into all aspects of property management to improve the level and efficiency of property management services, and continues to rely on the Internet technology and platform to develop new business. The above three property management conditions coexist in the current urban residential community. As people's requirements for quality of life improve, the low and middle level property management model will face upgrading and transformation, but how to better grasp the connotation of "Internet + property" model and develop a business form with high technical content and high added value of products have become a difficult problem for property management companies. How to better apply and promote high-level property management and improve the existing business model are also issues that need further consideration of high level property management.

\section{B. The Management of Property Management Enterprises Is Not Standardized, and There Is No Supervision Within the Enterprise and Industry}

The management system of most small and mediumsized property management enterprises is imperfect, the management technology level is backward, and the 
technology content is not high. For example, property management enterprises have several projects, and there is a certain distance from the headquarters. The headquarters often cannot respond to the problems transmitted by the community in time, so the management comes apart. Some managers have strong subjective consciousness, so they don't handle problems timely in accordance with the management regulations and the flexibility of handling problems is high, which makes the problems repetitive and they seldom make summary. In particular, small enterprises have less cost-investment in management mechanisms and lack professional management personnel. They have been operating in an inefficient and non-standard way for a long time. They have strong work arbitrarily and lack records for daily property management, which only meets immediate interests but lack a long-term vision of corporate development. At the same time, the relevant laws and regulations on property management are still not perfect, and the number of property management companies is large. It is only supervised by government departments and industry associations. The supervision coverage is too large, so the supervision is reduced accordingly.

\section{The Process of Property Management Service Lacks} Information Technology, Service Efficiency Is Not High, and the Contradiction Between Owners and Enterprises Is Increasing

In 2008, China Property Management Association promulgated the "Standards for Property Management Service Levels of Ordinary Residential Community", which specified different levels of property service projects and standards. Community owners and property management companies also signed standardized property service contracts that stipulate service items and fees. Most companies can provide corresponding services according to the agreement, but because of the lack of information technology in the service process, property services are inefficient. For example, the information of the residential community is published by means of paper printing and manual posting, of which the cost is high and the information transmission rate is hard to ensure. The users' feedback work and service follow-up work after the repairs and complaints are relatively lacking, and the file information management is urgently needed; the access control system improves security, but the manual registration method for outside personnel is hard to manage and there are loopholes. The surveillance and video is not installed in the community, so the property of the owner may suffer lost and cannot be further protected. The collection of water and electricity gas charges is manually recorded, manually recorded and manual calculated, so the accuracy is difficult to ensure, and the past records are not convenient to find. In order to increase profits and save operating costs, some enterprises can only reduce service standards in violation of the property contract, and reduce labor and necessary facilities maintenance expenses, resulting in the declining quality of basic cleaning, security, greening, maintenance and other services. Traditional business cannot be guaranteed, and new business can't keep up, causing dissatisfaction among the owners.

\section{The Quality of Property Personnel Is Uneven, and They Lack Professional and Systematic Training}

Property management is a staff-intensive service type. There are few high-level professional talents and they have entered the management. Those engaged in basic property management services such as cleaning, security, greening and maintenance are mostly low-level employees with uneven quality, so the management system can't keep up. Although most enterprises now need to train on-the-job personnel, many work experience cannot be well passed down and precipitated because of the large mobility of personnel. The personnel changes and quality problems further affect the quality of residential property services and affect the satisfaction of owners.

\section{THE DEVELOPMENT MODEL OF RESIDENTIAL PROPERTY MANAGEMENT UNDER THE BACKGROUND OF "INTERNET PLUS"}

In March 2015, Premier Li Keqiang first proposed the "Internet + " action plan in the government work report. In July of the same year, the State Council issued the "Guiding Opinions on Actively Promoting the "Internet +" Action", aiming to enhance the innovation capability of various industries and accelerate the industrial transformation and upgrading. "Internet + Property Management" is the development trend of the property management industry. On the one hand, it introduces new technologies, new methods and new formats in basic services such as traditional cleaning, security, greening and maintenance, and uses Internet platforms and resources to improve the efficiency of property management and improve the quality of property services. On the other hand, by integrating community business resources and third-party platforms, it builds an Internet platform to lead the owners to consume, and provides enterprises with a new profit model, thereby promoting the property management industry to move toward the modern service industry.

At present, some well-known property management companies have carried out the "Internet + Property" reform, and have innovated in business models, service methods and management methods. Among them, Vanke Property and Colour Life Property are all representative.

Vanke Property combines its own industry experience and mobile Internet and other technical means to create a "Wise Service" system. The Wise Service consists of four systems: standard training system, professional property division team system, partner management mechanism system, and Wise Platform data management system. "Wise Platform" includes the owner's mobile application "live here", the staff mobile phone application "help here", and the EBA remote equipment monitoring, operation system, the "war painting" that carry out online control of all facilities and equipment in the community operated by Vanke Property and customer management holographic view system, etc. ${ }^{1}$ It has realized the connection between

Vanke Property Development Co., Ltd. Interpretation of "Rui Service" System of Vanke Property [J]. China Property Management, 2014(9): 12-14. 
people and facilities, and the reporting and work orders have all been run online. Further, the connection between people, finances and materials has been realized. Not only the contract system is connected with the billing system, but also the online resources system controls employees and realizes the "datamation" for human, financial and material management. ${ }^{2}$ Among them, the owner-side mobile phone application "live here" realizes the functions of information release, maintenance and repair, property payment, neighborhood communication, and community activities, etc., and it also uses the Neighborhood Program. After the owner consumes in the "Neighborhood Market", the merchant pays a certain amount money to the user's community, which is used for hardware maintenance and cultural construction.

Color Life Property, formerly known as Shenzhen Fantasia Property Management Co., Ltd., is a technologybased and comprehensive property service operation group that integrates property services, building intelligence, asset operations and community services. ${ }^{3}$ The company advocates to make community service home, build B2F (Business To Family) model, and provide corresponding information and trading platform for owners and community businesses by setting up Internet platform, cloud computing platform and Internet of Things platform. The company has developed the "colorful cloud" community service platform, which has realized basic property services such as property collection, complaints and warranty, community notification, parking, access control, and cleaning, etc. At the meanwhile, there are more supporting living services including living supermarkets, convenience services, leisure and entertainment, and education and training, etc. Through the creation of a one-kilometer community business ecosystem, it can meet the needs of the community owners in clothing, food, housing, travel, play, purchase, and travel. The smart community ecosystem built by Color Life will transform the management of "things" into a service for "people" and create a one-stop community life service platform for the owners.

In addition to the large-scale property management companies joining the "Internet + " camp, there are many property management companies gradually began to use information technology to upgrade property management services. But in the process, there have been many problems. First, some enterprises did not seriously analyze their own advantages and disadvantages and the situation of the community itself when finding the right Internet property management model for enterprises, which not only increased the equipment input cost, but also easily led to the loss of the Internet. Second, the Internet platform was available, but the customer failed to effectively use the platform. In addition to routine services such as daily payment, other life-supporting services are rarely used, and the activity is not high, making the built-up community life circle a waste; third is the lack of compound talents for

\footnotetext{
Https://www.vankeservice.com/business.aspx?type=13, Vanke Property

https://baike.baidu.com/item/\%E5\%BD\%A9\%E7\%94\%9F\%E6 \%B4\%BB/7911287?fr=aladdin, Baidu Encyclopedia
}

"Internet + property management". Due to salary and other issues, it is difficult for property companies to attract talented people to join, especially those who master both Internet operations and property management. Fourth, there are more small businesses in the property management industry. Satisfied with the existing model and operating status, they lack motivation for change in developing "Internet +" business.

\section{SUGGESTIONS ON THE INNOVATION OF THE RESIDENTIAL PROPERTY MANAGEMENT UNDER INTERNET THINKING}

The earliest proposer of the concept "internet thinking" is the founder of Baidu, Li Yanhong. It refers to the way of thinking that reviews the market, users, products, enterprise value chain and even the entire business ecosystem in the context of the continuous development of mobile Internet, big data, and cloud computing and other technologies. Zhou Hongyi, chairman of 360 Company, believes that in the Internet era, firstly, user is supreme; secondly, experience is most importance; third is free business model, and the fourth is subversive innovation. ${ }^{4}$ The founder of Xiaomi company, Lei Jun, believes that Internet thinking has sevencharacter formula: focus, extreme, word of mouth, and fast; ${ }^{5}$ In conclusion, to develop property management with Internet thinking, we must: first, focus on core work; second, focus on user experience and needs; third, expand the brand and optimize management to achieve word of mouth effect; fourth, there must be innovation.

First, they focus on core work. The basic business of the property management company is to maintain and repair the house and ancillary equipment, maintenance of safety and order, sanitation and cleaning, and green maintenance. The core of the work lies in the "service", which means enhancing the level of specialization and maximizing the service business. Vanke Property is a model in this regard, which through the connection of big data, Internet of Things and Internet technology, establishes the connection between things and things, and people and things. For example, it establishes a network platform and uses remote monitoring technology, and automation technology, etc. in the maintenance of facilities and equipment to grasp the operation of the equipment. It can automatically connect the staff in case of failure, and carry out maintenance management at the fastest speed; in public security management, the monitoring equipment and sensing equipment are installed inside the community to realize the comprehensive monitoring of the community, and the access control system is upgraded to facilitate the tracking of outside personnel and ensure the safety of the owner's personal property. At the same time, the monitoring system is used to ensure firefighting and security; it uses the Internet network platform to handle customer service

\footnotetext{
4 https://baike.baidu.com/item/\%E4\%BA\%92\%E8\%81\%94\%E7\% BD\%91\%E6\%80\%9D\%E7\%BB\%B4/12028763?fr=aladdin\#reference -[5]13580621-wrap Baidu Encyclopedia

Zheng Yanfang. Lei Jun - The forerunner of Internet thinking [M]. Beijing: Posts and Telecom Press, 2016:166.
} 
projects, including repairs, collection fees, and information release, etc., and do a good job of tracking feedback. The platform should be convenient for customers to use, achieve the simple, efficient, and professional effect, and let customers participate in property management to understand the entire property operation of the community. Only by creating a high level of service can customers have a sense of trust in property management companies, thereby consolidating and maintaining customers and laying the foundation for further value-added services.

Second, they attach importance to user experience and needs. After improving the informationization of basic business, property management companies should pay attention to user feedback, cultivate customer's goodwill and satisfaction, and at the same time expand more value-added services to create a "one-kilometer community life circle". The specific model is $\mathrm{O} 2 \mathrm{O}$ (Online To Offline) and $\mathrm{B} 2 \mathrm{~F}$ (Business to Family). The $\mathrm{O} 2 \mathrm{O}$ model is centered on the community and serves the owner's life. It uses Internet technology to integrate online and offline resources around the community, and builds a platform between users and merchants and on-site service providers. The B2F model refers that the property management company provides value-added services directly to the needs of the family using the Internet's platform and community resources, such as family services that meet the family, pension services, and travel services. ${ }^{6}$ The property management enterprise should analyze the data of the internal environment of the community, the external business resources, the consumption habits of the owners, the consumption power and the consumption preferences before selecting the specific model, and create the most suitable community life circle for each project to provide services such as supermarkets, catering, housekeeping, tourism, education, financial management, medical care, and law, etc. Each service should pay attention to the user experience, and everything is user-centered. At the same time, it should consider whether they need to introduce specialized thirdparty institutions to complement each other's advantages and achieve win-win results, thus avoiding wasting research and development resources. Only when the needs of the owners are satisfied can the loyalty and brand dependence of the property management enterprises be cultivated.

Third, they enlarge the brand and optimize management to achieve word-of-mouth effect. In the "Internet +" era, small business resources are scarce, so companies can achieve cooperation and mergers and acquisitions, integrate multiple enterprises resources, and build brand awareness. Brand building is the foundation of enterprise development, of which the connotation includes popularity, loyalty, and satisfaction, and so on. With the brand effect, it can attract more customers and realize greater development of the company. Enterprises should also achieve management upgrades, use information technology to build management and control systems at all levels, improve property management efficiency, reduce property management costs,

6 Liu Tao. Study on the Problem of Property Management against the Background of "Internet +"[J]. Times Financial, 2017(04): 284,298. introduce excellent management talents, and establish good management mechanisms. At the same time, it should give full play to the management and supervision functions of different entities such as owners, enterprises, industries and governments to improve relevant laws and regulations and guide enterprises in orderly, standardized and long-term development. Only when the enterprise develops well can the owner's stickiness to the property management enterprise be increased. They will rely on the information platform from the basic service to the community service and the social media is used to realize the word-of-mouth publicity.

Fourth, there must be innovation. The user data and equipment status of property management company should be kept updated, and at the same time, technological innovation and thinking innovation are needed, which is inseparable from professional talents. The property management industry currently lacks the "Internet + property management" compound talents, so it can increase the training of employees, enhance the professionalization of employees through systematic learning, strengthen the assessment of employees' professional skills and professional ethics, encourage employees to get the property management division qualifications, and create a scientific promotion mechanism and salary system for employees; at the same time, enterprises can cooperate with colleges and universities to carry out order-based training and make preparation for the property management industry to reserve talents.

\section{CONCLUSION}

Property management enterprises in the Internet era must be prepared for change, use information technology to start from upgrading basic property services, further build community living circles to meet the multi-faceted needs of owners, and use Internet thinking to effectively improve management and service capabilities, so as not to be eliminated by the times.

\section{REFERENCES}

[1] Vanke Property Development Co., Ltd. Interpretation of "Rui Service" System of Vanke Property [J]. China Property Management, 2014(9): 12-14.

[2] Huang Huan. A new model of "Color Life" property service [J]. Real Estate Information of China, 2015(5): 20-24.

[3] Yu Jing. Leijun of Xiaomi: I finally understand the Internet thinking [EB/OL].http://www.woshipm.com/pd/98062.html, 2014-08-6.

[4] Zhang Zhuting. Research and Innovation of Property Management Mode Based on Internet in Residential community [D]. Zhejiang University of Technology, 2015.

[5] Liu Tao. Study on the Problem of Property Management under the Background of "Internet +"[J].Times Financial,2017(04):284,298.

[6] Ma Yunyan. Innovative exploration of Property Management in Residential community under the Background of "Internet + "[J] Industrial \& Science Tribune, 2015(24):253-254.

[7] Yao Jianxiong, Tan Qing, Geng Zilong. Understanding and Reflection on the Internet + Property Service Model[J]. Enterprise Reform and Management, 2017(3): 76-77. 
[8] Chen Shiqing, Huang Ruli. Discussion on Service Innovation of Property Management Enterprises in Residential community under Internet Thinking[J]. Jiangsu Commercial Forum, 2017(10):82-84. 